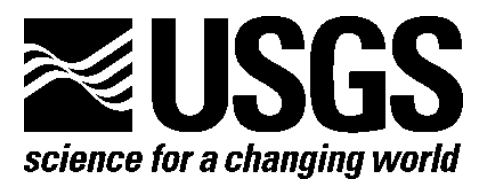

Prepared in cooperation with the State of Hawaii Department of Transportation

Rainfall, Discharge, and Water-Quality Data During Stormwater Monitoring, H-1 Storm Drain, Oahu, Hawaii, July 1, 2009, to June 30,2010

By Todd K. Presley and Marcael T.J. Jamison

Open File Report 2010-1161

U.S. Department of the Interior

U.S. Geological Survey 


\section{U.S. Department of the Interior \\ KEN SALAZAR, Secretary}

\section{U.S. Geological Survey \\ Marcia K. McNutt, Director}

U.S. Geological Survey, Reston, Virginia 2010

For product and ordering information:

World Wide Web: http://www.usgs.gov/pubprod

Telephone: 1-888-ASK-USGS

For more information on the USGS-the Federal source for science about the Earth,

its natural and living resources, natural hazards, and the environment:

World Wide Web: http://www.usgs.gov

Telephone: 1-888-ASK-USGS

Suggested citation:

Presley, T.K., and Jamison, M.T.J., 2010, Rainfall, discharge, and water-quality data during stormwater monitoring, H-1 storm drain, Oahu, Hawaii, July 1, 2009, to June 30, 2010: U.S. Geological Survey Open-File Report 2010-1161, $26 \mathrm{p}$.

Any use of trade, product, or firm names is for descriptive purposes only and does not imply endorsement by the U.S. Government.

Although this report is in the public domain, permission must be secured from the individual copyright owners to reproduce any copyrighted material contained within this report. 


\section{Contents}

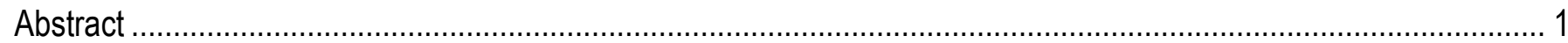

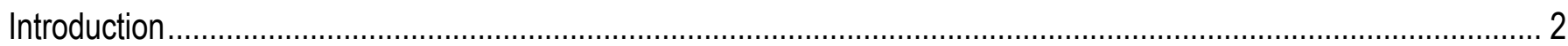

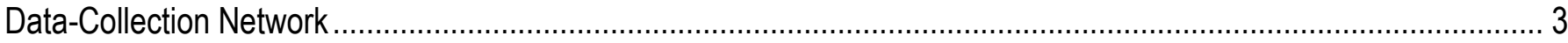

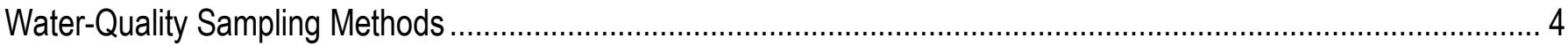

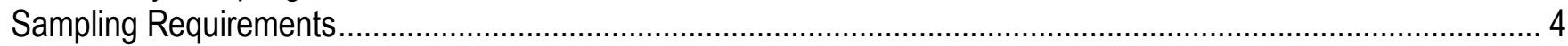

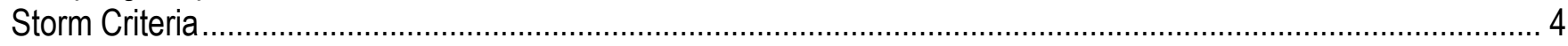

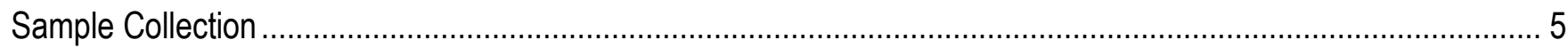

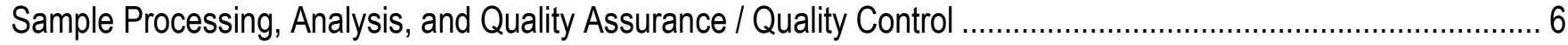

Determination of Discharge and Constituent Load Associated with Samples .................................................... 7

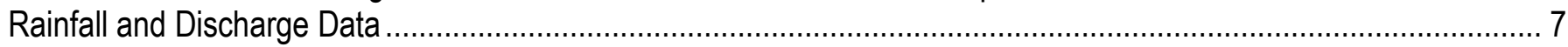

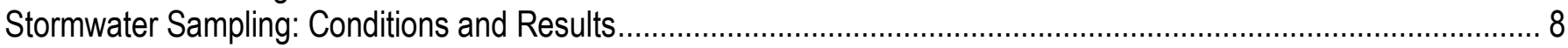

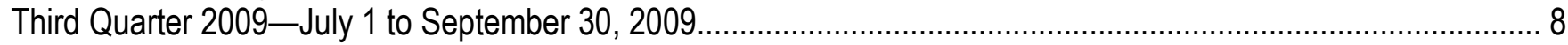

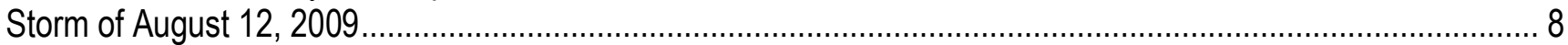

Fourth Quarter 2009-October 1 to December 31, 2009 ….................................................................... 8

First Quarter 2010-January 1 to March 31, 2010 ............................................................................... 9

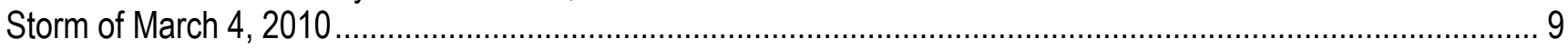

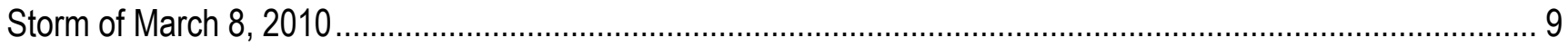

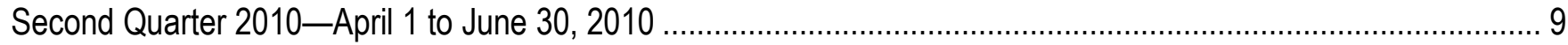

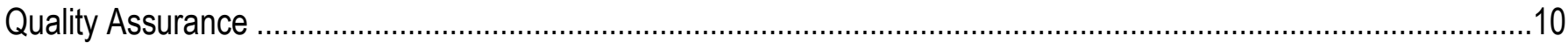

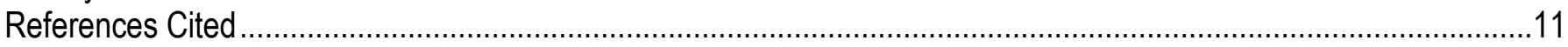

Appendix A. Discharge-Reporting and Load-Calculation Methods ...............................................................19

Appendix B. Physical Properties, Concentrations, and Loads for All Samples Collected from the H-1 Storm Drain and the Manoa-Palolo Drainage Canal During the Period from July 1, 2009, to June 30, 2010, Oahu, Hawaii...................21

\section{Figures}

1. Drainage area of the $\mathrm{H}-1$ storm drain and locations of the $\mathrm{H}-1$ rain gage, $\mathrm{H}-1$ storm drain gage, and the $\mathrm{H}-1$ storm drain and Manoa-Palolo Drainage Canal sampling sites, Oahu, Hawaii............................................................ 13

2. Daily rainfall and daily mean discharge for $\mathrm{H}-1$ rain gage (211722157485602) and $\mathrm{H}-1$ storm drain (211722157485601) within the Ala Wai Canal watershed, Oahu, Hawaii, for July 1, 2009 to June 30, 2010 ............. 14 3. Discharge at H-1 storm drain (211722157485601), Oahu, Hawaii, for July 1 to September 30, 2009 (top), detail of 4-day period from August 10 to 13, 2009 (middle), and detail of 10-hour period from 22:00 August 11 to 08:00 August

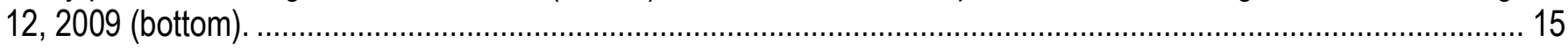

4. Discharge at H-1 storm drain (211722157485601) for October 1 to December 31, 2009, Oahu, Hawaii. .............. 16

5. Discharge at H-1 storm drain (211722157485601), Oahu, Hawaii, for January 1 to March 31, 2010 (top), detail of 4-day period from March 6 to 10, 2010 (middle), and detail of 10-hour period from 22:00 March 7 to 08:00 March 8, 2010 (bottom).

6. Discharge at H-1 storm drain (211722157485601) for April 1 to June 30, 2010, Oahu, Hawaii............................ 18

\section{Tables}

1. Significant figures and rounding limits for measured, discharge-rating, and averaged discharges ........................ 19

2. Conversion factors for computing daily loads from constituent concentration and discharge. .............................. 20

3. Physical properties, concentrations, and loads for all samples collected from the H-1 storm drain and the Manoa-

Palolo Drainage Canal during the period from July 1, 2009, to June 30, 2010, Oahu, Hawaii. 


\section{Conversion Factors}

Inch/Pound to SI

\begin{tabular}{|c|c|c|}
\hline Multiply & By & To obtain \\
\hline \multicolumn{3}{|c|}{ Length } \\
\hline inch (in.) & 2.54 & centimeter $(\mathrm{cm})$ \\
\hline foot (ft) & 0.3048 & meter (m) \\
\hline mile (mi) & 1.609 & kilometer (km) \\
\hline \multicolumn{3}{|c|}{ Flow rate } \\
\hline cubic foot per second $\left(\mathrm{ft}^{3} / \mathrm{s}\right)$ & 0.02832 & cubic meter per second $\left(\mathrm{m}^{3} / \mathrm{s}\right)$ \\
\hline
\end{tabular}

Temperature in degrees Celsius $\left({ }^{\circ} \mathrm{C}\right)$ may be converted to degrees Fahrenheit $\left({ }^{\circ} \mathrm{F}\right)$ as follows:

${ }^{\circ} \mathrm{F}=\left(1.8 \times{ }^{\circ} \mathrm{C}\right)+32$

Temperature in degrees Fahrenheit $\left({ }^{\circ} \mathrm{F}\right)$ may be converted to degrees Celsius $\left({ }^{\circ} \mathrm{C}\right)$ as follows:

${ }^{\circ} \mathrm{C}=\left({ }^{\circ} \mathrm{F}-32\right) / 1.8$

Vertical coordinate information is referenced relative to mean sea level.

Horizontal coordinate information for Figure 1 is referenced to the North American Datum of 1983 (NAD 83).

Altitude, as used in this report, refers to distance above the vertical datum.

Specific conductance is given in microsiemens per centimeter at 25 degrees Celsius $\left(\mu \mathrm{S} / \mathrm{cm}\right.$ at $\left.25^{\circ} \mathrm{C}\right)$.

Concentrations of chemical constituents in water are given either in milligrams per liter (mg/L) or micrograms per liter $(\mu \mathrm{g} / \mathrm{L})$. 


\title{
Rainfall, Discharge, and Water-Quality Data During Stormwater Monitoring, H-1 Storm Drain, Oahu, Hawaii, July 1, 2009, to June 30,2010
}

\author{
By Todd K. Presley and Marcael T.J. Jamison
}

\begin{abstract}
Storm runoff water-quality samples were collected as part of the State of Hawaii Department of Transportation Stormwater Monitoring Program. The program is designed to assess the effects of highway runoff and urban runoff collected by the H-1 storm drain on the Manoa-Palolo Drainage Canal. This report summarizes rainfall, discharge, and water-quality data collected between July 1, 2009, and June 30, 2010.

As part of this program, rainfall and continuous discharge data were collected at the $\mathrm{H}-1$ storm drain. During the year, sampling strategy and sample processing methods were modified to improve the characterization of the effects of discharge from the storm drain on the Manoa-Palolo Drainage Canal. During July 1, 2009, to February 1, 2010, samples were collected from only the H-1 storm drain. Beginning February 2, 2010, samples were collected simultaneously from the H-1 storm drain and the Manoa-Palolo Drainage Canal at a location about 50 feet upstream of the discharge point of the H-1 storm drain.

Three storms were sampled during July 1, 2009, to June 30, 2010. All samples were collected using automatic samplers. For the storm of August 12, 2009, grab samples (for oil and grease, and total petroleum hydrocarbons) and a composite sample were collected. The composite sample was analyzed for total suspended solids, nutrients, and selected dissolved and total (filtered and unfiltered) trace metals (cadmium, chromium, nickel, copper, lead, and zinc). Two storms were sampled in March 2010 at the H-1 storm drain and from the Manoa-Palolo Drainage Canal. Two samples were collected during the storm of March 4, 2010, and six samples were collected during the storm of March 8, 2010. These two storms were sampled using the modified strategy, in which discrete samples from the automatic sampler were processed and analyzed individually, rather than as a composite sample, using the simultaneously collected samples from the $\mathrm{H}-1$ storm drain and from the Manoa-Palolo Drainage Canal. The discrete samples were analyzed for some or all of the following constituents: total suspended solids, nutrients, oil and grease, and selected dissolved (filtered) trace metals (cadmium, chromium, nickel, copper, lead, and zinc).

Five quality-assurance/quality-control samples were analyzed during the year. These samples included one laboratory-duplicate, one field-duplicate, and one matrix-spike sample prepared and analyzed with the storm samples. In addition, two inorganic blank-water samples, one sample at the H-1 storm drain and one sample at the Manoa-Palolo Drainage Canal, were collected by running the blank
\end{abstract}


water (water purified of all inorganic constituents) through the sampling and processing systems after cleaning automatic sampler lines to verify that the sampling lines were not contaminated.

\section{Introduction}

The State of Hawaii Department of Transportation (DOT) Stormwater Monitoring Program Plan (State of Hawaii Department of Transportation Highways Division, 2008, 2009) was implemented on January 1, 2001. Water-quality monitoring was conducted on the Halawa Stream drainage basin, Oahu, Hawaii, during 2001 to 2009. In 2005, additional monitoring of a storm drain that collects runoff from the H-1 Freeway was implemented to fulfill requirements, outlined by the United States Environmental Protection Agency (USEPA), related to total maximum daily loads (TMDL) for total nitrogen and total phosphorous (U.S. Environmental Protection Agency, Region 9, and Hawaii Department of Health, 2002) for discharges into the Manoa-Palolo Drainage Canal. Rainfall, discharge, and water-quality data were collected at the H-1 storm drain starting in 2006.

The DOT Stormwater Monitoring Program Plan was designed to fulfill part of the permit requirements for the National Pollutant Discharge Elimination System program and is revised yearly. The DOT Stormwater Monitoring Program Plan requires the collection of rainfall, discharge, and waterquality data.

This report summarizes water-quality data collected during July 1, 2009, to June 30, 2010, by the U.S. Geological Survey (USGS) as part of the DOT Stormwater Monitoring Program Plan. This report also presents rainfall and discharge data collected from July 1, 2009, to June 30, 2010, for the storm drain of the H-1 Freeway (hereinafter referred to as the H-1 storm drain) that discharges into the Manoa-Palolo Drainage Canal.

During the year of this study, sampling strategy and sample processing methods were modified to improve the characterization of the effects of discharge from the storm drain on the Manoa-Palolo Drainage Canal. Water-quality data are presented from a new site established in February 2010 that collects samples from the Manoa-Palolo Drainage Canal upstream of the discharge location of the $\mathrm{H}-1$ storm drain. Descriptions of the sampling techniques are included with the water-quality data.

Water-quality samples were collected at the H-1 storm drain for three storms during July 1 , 2009, to June 30, 2010. Water-quality samples also were collected at the Manoa-Palolo Drainage Canal during the last two of the three storms. All samples from the H-1 storm drain and the Manoa-Palolo Drainage Canal sites were collected using automatic samplers.

Five quality-assurance/quality-control (QA/QC) samples were collected concurrently with storm samples and during routine cleaning of the sampling equipment between storms. These QA/QC samples included one laboratory-duplicate sample, one field-duplicate sample, and one matrix-spike sample, as well as two blank-water samples. A blank-water sample consists of inorganic blank water (water purified of all inorganic constituents) which is passed through cleaned sampling lines, automatic samplers, and processing equipment to verify that the sampling equipment was not contaminated. Water-quality data for the QA/QC samples are not published in this report, but they are available upon request from the USGS Pacific Islands Water Science Center in Honolulu, Hawaii. 


\section{Data-Collection Network}

Discharge, rainfall, and water-quality data were collected at the H-1 storm drain site (fig. 1). Since April 6, 2006, discharge data have been collected at station 211722157485601, H-1 Storm Drain at Kapiolani Boulevard, Oahu, HI (abbreviated to H-1 storm drain), and rainfall data were collected at station 211722157485602, State Key Number 711.7 H-1 Rain Gage at Kapiolani Boulevard, Oahu, HI (abbreviated to $\mathrm{H}-1$ rain gage). The $\mathrm{H}-1$ rain gage is located on the roof of the $\mathrm{H}-1$ storm drain gage house.

Rainfall and discharge data were collected using variable sampling intervals, depending on discharge rates. Because of difficulties in measuring discharge directly at the $\mathrm{H}-1$ storm drain in order to create a rating, stage-discharge ratings were developed using only the results from analysis involving hydraulic models of culvert flow. Methods for culvert flow analysis can be found in Bodhaine (1982) and Fulford (1995). USGS practices for making discharge measurements and stage-discharge ratings can be found in Rantz and others (1982). Discharge and rainfall data from the H-1 storm drain are transferred to the National Water Information System (NWIS) database hourly by satellite telemetry.

Recent data can be viewed at http://hi.water.usgs.gov/ under "Real-Time Data” by selecting "Streamflow" or "Rainfall” and then selecting the appropriate USGS station numbers. Historical dailymean streamflow data can be accessed through the website http://hi.water.usgs.gov/ under "Historical Data” by selecting "Streamflow," selecting “Daily Data," and then entering the appropriate USGS station numbers. Historical instantaneous streamflow data can be accessed through the website http://hi.water.usgs.gov/ under "Historical Data” by selecting “Instantaneous Data Archive (IDA),” and then selecting the appropriate USGS station numbers and dates. Historical rainfall data can be accessed through the website http://hi.water.usgs.gov/ under "Historical Data” by selecting "Rainfall," and then selecting the appropriate USGS station numbers.

The H-1 storm drain collects runoff that flows southeast to northwest over about $1.3 \mathrm{mi}$ of freeway (fig. 1). Runoff from part of the neighborhood adjacent to the freeway also drains into the drainage system connected to the storm drain. The H-1 storm drain discharges into the Manoa-Palolo

Drainage Canal near the intersection of King Street and Kapiolani Boulevard, under the viaducts of the freeway and eastbound onramp. The discharge point of the storm drain is along a sloping wall about 10 $\mathrm{ft}$ higher than the bed of the drainage canal, about $500 \mathrm{ft}$ downstream of the confluence of Palolo and Manoa Streams. The gage house of the $\mathrm{H}-1$ storm drain station is located directly above the discharge point of the drain. A second site was installed to collect samples from the Manoa-Palolo Drainage Canal. Station 211722157485603, Manoa-Palolo Drainage Canal at H-1 Freeway, Oahu, HI (abbreviated to Manoa-Palolo Drainage Canal), is about 50 feet upstream of the storm-drain discharge (fig. 1). No discharge or stage is measured from the Manoa-Palolo Drainage Canal site; however, the USGS operates two nearby gages: 16242500 Manoa Stream at Kanewai Field, Honolulu, Oahu, HI, which measures discharge in Manoa Stream about 1,800 feet upstream of the H-1 storm drain site, and 16247100 Manoa-Palolo Drainage Canal at Moiliili, Oahu, HI, located about 1,500 feet downstream of the storm drain site. Discharge at station 16247100 is tidally influenced during low flow.

Automatic samplers for collection of water-quality samples are installed at the $\mathrm{H}-1$ storm drain and Manoa-Palolo Drainage Canal sites. The sampler at the $\mathrm{H}-1$ storm drain has been operational since 2006. The sampler at the Manoa-Palolo Drainage Canal site was installed and operational beginning in February, 2010. The Manoa-Palolo Drainage Canal site was set up to sample water from the drainage canal simultaneously with collecting samples at the $\mathrm{H}-1$ storm drain.

Water-quality data that have been collected at H-1 storm drain (2006 to present) and the ManoaPalolo Drainage Canal (2010) by the USGS can be viewed at the website http://hi.water.usgs.gov/ under 
"Historical Data” by selecting "Water Quality”, then selecting “Field/lab samples,” then selecting under the "Site -Identifier_-" column the box adjacent to "Site Number," and then entering the appropriate USGS station number.

\section{Water-Quality Sampling Methods}

Water-quality samples at the H-1 storm drain and the Manoa-Palolo Drainage Canal include grab samples, time-composite samples, and discrete samples, all of which were collected by automatic samplers. Because of a change in project objectives within the year, two different automatic samplecollection strategies and techniques were used during the year.

\section{Sampling Requirements}

The DOT Stormwater Monitoring Program Plan states that water-quality samples will be collected at least once per quarter during periods of storm runoff from the $\mathrm{H}-1$ storm drain. However, if a storm does not occur during a quarter, no samples will be collected. Some storms are brief and do not produce adequate runoff to collect all samples. In practice, storms were sampled as thoroughly as possible and analyzed for as many constituents as was practical.

The DOT Stormwater Monitoring Program Plan (2008) describes the procedures for sampling that were applied during July 1, 2009, to February 1, 2010. Grab and time-composite samples were collected only at the H-1 storm drain. Grab samples are those samples used for analyses of oil and grease or total petroleum hydrocarbon. Time-composite samples were created in an effort to describe the chemical composition of the water from the storm drain for the whole storm. Time-composite samples are produced by combining the contents of some or all of the samples collected by the automatic sampler. Historically, time-composite samples prepared for the H-1 storm drain were not flow-weighted composite samples, because only a few samples were collected during the brief periods of flow, and using flow-weighting techniques would yield insufficient sample volume for analyses.

The DOT Stormwater Monitoring Program Plan (2009) describes procedures for sampling that were applied during February 2 to June 30, 2010. As mentioned above, a second sampler was installed to sample water from the Manoa-Palolo Drainage Canal. Only discrete samples were collected at the H1 storm drain and Manoa-Palolo Drainage Canal sites during this period. Discrete samples are single bottles of sample that are split into subsamples for various analyses. Discrete samples are used to determine chemical composition at different times during the storm, in contrast to previous efforts to characterize the whole storm by creating time-composite samples. Logging equipment was reprogrammed to collect samples at 15-minute fixed intervals. Discrete samples from the H-1 storm drain and the Manoa-Palolo Drainage Canal were collected using larger, 1-gallon glass bottles so that sufficient sample volume would be available for all of the desired analyses.

\section{Storm Criteria}

The USEPA Storm Water Sampling Guidance Manual (U.S. Environmental Protection Agency, Office of Water, 1993) provides criteria for stormwater sampling. The first criterion requires at least 0.1 in. of accumulated rainfall during a storm. Rainfall accumulations exceeded 0.1 in. at the H-1 storm drain when stormwater sampling was conducted. The second criterion requires that samples be collected only for storms preceded by at least 72 hours of dry weather. The second criterion would prevent 
sampling of most storms because many parts of Oahu receive tradewind showers almost daily. Many of the samples collected in the past do not meet the second criterion.

In practice, criteria used to initiate sampling were based on the rate of rainfall accumulation and the rise of stage in the $\mathrm{H}-1$ storm drain. The automatic sampler is triggered at a specific stage threshold determined after investigating the relation between rainfall and runoff.

\section{Sample Collection}

Automatic samplers collect water from a fixed point in the stream channel after predetermined stage thresholds are met. Grab, time-composite, and discrete samples are assigned sampling times on the basis of the data from the gage logging systems. Mean sampling times for time-composite samples are computed from the first and last collection times of the samples used for the composite samples.

Two automatic sampler strategies were employed during the period from July 1, 2009, to June 30, 2010.

Sampling Equipment and Methods During July 1, 2009, to February 1, 2010.- The automatic sampler for the H-1 storm drain was configured to collect samples using 24 bottles of 1-liter capacity. When the first threshold has been met, the automatic sampler was programmed to collect water samples every 2 minutes for the first 5 samples and then every 15 minutes for the remaining 19 samples. The first stage threshold for the sampler corresponded to a discharge of about $2.4 \mathrm{ft}^{3} / \mathrm{s}$. To enable collection of a sufficient volume of water in each sample during storms with rapid rising and falling stage, or high overall flow, a second stage threshold was used to trigger the samplers to sample every 7 minutes. This higher stage threshold corresponded to a discharge of $56 \mathrm{ft}^{3} / \mathrm{s}$.

The automatic sampler was set up with "bottles” that are actually bags held in bottle-like frames. The bags were either reusable and made of teflon that could be cleaned or disposable and made of low density polyethylene (LDPE). The teflon bags were positioned in the first 3 slots of the sampler, and the LDPE bags were positioned in the remaining 21 slots. Water samples collected in the teflon bags were sometimes analyzed as grab samples for oil and grease $(\mathrm{O}+\mathrm{G})$ and total petroleum hydrocarbons (TPH). The main limitations of using water collected in the teflon bags for $\mathrm{O}+\mathrm{G}$ and $\mathrm{TPH}$ analyses are that (1) analyses for these constituents require that the samples be chilled before analysis and analyzed within a certain time after collection, known as the "holding time," and (2) these constituents may adhere to tubing lines used to collect the sample.

The DOT Stormwater Monitoring Program Plan (2008) states that time-composite samples should be created by combining flow-weighted samples from the automatic sampler. A flow-weighted composite sample is created by combining specific volumes of water from each sample, the amount being proportional to the volume of stream discharge between sample collection times. Flow-weighted composite samples are collected over time periods that sometimes last several hours. A time-composite sample that is not flow-weighted is created by combining the entire contents of bottles, with no weighting proportional to stream discharge. Owing to the short duration of storms, the low number of samples collected during storms, or storms with multiple discharge peaks separated by an hour or more, using the flow-weighting method does not allow for a sufficient combined volume of water for samples from the H-1 storm drain. As a result of conditions at the storm drain, none of the time-composite samples were flow-weighted.

At the $\mathrm{H}-1$ storm drain, when practical, samples from the first two bottles were used for $\mathrm{O}+\mathrm{G}$ and TPH analyses and were labeled as grab samples. The remainder of the samples were combined to create time-composite samples. 
Sampling Equipment and Methods During February 2 to June 30, 2010.-A discrete-sample strategy was adopted to characterize changes of concentration of constituents through the rise and fall of the flow in the H-1 storm drain and to compare water-quality samples, collected simultaneously, between the H-1 storm drain and the Manoa-Palolo Drainage Canal (DOT Stormwater Monitoring Program Plan, 2009). As mentioned above, a second sampler was installed to sample the Manoa-Palolo Drainage Canal. Discrete samples represent the runoff composition at the time the sample was taken. Discrete samples allow for evaluation of how constituent concentrations vary with time and with changes in discharge during the storm.

The data-logging system at the $\mathrm{H}-1$ storm drain was reconfigured to simultaneously trigger the samplers at the H-1 storm drain and the Manoa-Palolo Drainage Canal at a fixed interval of 15 minutes after a threshold of flow (corresponding to $2.4 \mathrm{ft}^{3} / \mathrm{s}$ ) in the storm drain was met. No second threshold was used. The samplers were configured with a base that holds four 1-gallon glass jars in order to collect enough water for the required analyses over a short and discrete time. For a given storm, a maximum of four samples were collected over a period that could be as short as 45 minutes.

\section{Sample Processing, Analysis, and Quality Assurance I Quality Control}

USGS water-quality sampling methods (Wilde and others, 1998) were followed to prevent possible contamination during sample processing.

Processing and Analyses, July 1, 2009, to February 1, 2010.-Grab samples collected by the automatic sampler for $\mathrm{O}+\mathrm{G}$ and TPH analyses were poured directly from the 1-liter sample collection bottles into the analysis bottles. Time-composite samples were poured directly into HDPE churns. Churns are used to mix and suspend sediment in order to deliver homogeneous sample to specific bottles for the various constituent analyses.

As required by the DOT Stormwater Monitoring Program Plan, grab samples were analyzed for $\mathrm{O}+\mathrm{G}$ and TPH only, and time-composite samples were analyzed for total suspended solids (TSS), nutrients, and selected total trace metals (cadmium, chromium, copper, lead, zinc, and nickel). If sufficient sample volume was available, the same selected trace metals also were analyzed after filtering (dissolved trace metals).

Processing and Analyses, February 2, 2010, to June 30, 2010.-The discrete 1-gallon samples were poured directly into HDPE churns. Constituents analyzed included $\mathrm{O}+\mathrm{G}$, total suspended solids (TSS), nutrients, and selected dissolved (filtered) trace metals (cadmium, chromium, copper, lead, zinc, and nickel).

Laboratory Analyses.--O+G and TPH were analyzed at the Test America Laboratories facility in Denver, Colorado. All other analyses, including laboratory analyses of $\mathrm{pH}$ and specific conductance, were done at the USGS National Water Quality Laboratory (USGS NWQL) in Denver, Colorado. The methods used for analyses of all water-quality constituents and quality-control practices at the USGS NWQL are documented in Friedman and Erdmann (1982), Fishman and Friedman (1989), Pritt and Raese (1992), Patton and Truitt (1992), Fishman (1993), Hoffman and others (1996), Garbarino and Struzeski (1998), and Garbarino and others (2006). Data values published in this report with "less-than" symbols $(<)$ are below the minimum reporting level. Minimum reporting levels for each of the analyzed properties and constituents are determined by the USGS NWQL and have changed through time as methods and equipment improved, or if the criteria used to set the minimum reporting levels changed. The calculated values of organic nitrogen and total nitrogen do not have minimum reporting levels. More information about minimum reporting levels and how they are determined by the USGS NWQL can be found in Childress and others (1999). 
Quality Assurance/Quality Control.-Collection of field-duplicate, laboratory-duplicate, and matrix-spike samples during the sampling year is required by the DOT Stormwater Monitoring Program Plan. A field-duplicate sample is collected concurrently with the storm sample, or split from a single, larger volume of sample. The analytical results of the two samples are used to verify the sampling method. A laboratory-duplicate sample is obtained by splitting a sample into two equal parts during sample analysis, and the results are used to verify the precision of the laboratory. A matrix-spike sample is created by adding a known amount of constituent to a storm sample, and the results are used to test recovery of the constituent in the storm-sample medium.

During the period between storms, nondedicated and nondisposable equipment, such as churns, graduated cylinders, peristaltic pump tubes, teflon automatic-sampler bottle liners, and 1-gallon glass bottles, were cleaned following procedures in Wilde and others (1998).

As a check of the sampler intake lines and bags, inorganic blank water (IBW), free of inorganic constituents, was passed through the automatic sampler and collected as "field-blank" samples. The intake lines were cleaned following procedures in Wilde and others (1998) before the collection of the field-blank samples. The IBW field-blank samples were analyzed for the same inorganic constituents as the storm samples.

\section{Determination of Discharge and Constituent Load Associated with Samples}

At the H-1 storm drain, discharge associated with each sample was determined using a stagedischarge rating created for the station.

An average discharge value was calculated for each composite sample. The average-discharge value was equal to the total volume of water that flowed by the gaging station during sample collection, divided by the total elapsed time of sample collection. To determine the volume of water that passed the station for each sample, the discharge at the time of sample collection was multiplied by the elapsed time. The elapsed time for each sample is the amount of time between the sample in question and the prior sample. To compute the elapsed time of the first sample, the amount of time between the first and second samples is used. The volumes and elapsed times for each sample were summed, and the total volume was divided by the total elapsed time.

Stage-discharge rating and averaged discharge values are reported to appropriate numbers of significant figures. These discharge values and the corresponding values of constituent concentrations are used to compute loads. Reported discharge values and the calculation of loads are discussed in appendix A. Table 1 shows the number of significant figures for the range of discharge values, and table 2 shows the conversion factors for computing loads from constituent concentration and discharge.

\section{Rainfall and Discharge Data}

Hydrographs of daily rainfall and daily mean discharge for the period of July 1, 2009, through June 30, 2010, are shown in figure 2 for the $\mathrm{H}-1$ rain gage and the $\mathrm{H}-1$ storm drain station. The rainfall record is complete except for a few hours of missing data on August 3 and September 29, 2009. Total rainfall at the H-1 rain gage was 12.89 in. during July 1, 2009, through June 30, 2010, compared to 24.4 in. during the previous year. For the year, the highest recorded daily rainfall was 1.06 in. on December 3 , 2009. The discharge record is complete for the year; however, during periods when the storm drain is dry, discharge is estimated as zero. The highest daily mean discharge was $1.5 \mathrm{ft}^{3} / \mathrm{s}$ on December 3 , 2009. The highest instantaneous discharge was $73 \mathrm{ft}^{3} / \mathrm{s}$ at 19:40 on December 3, 2009. There were 227 
days with zero rainfall, 288 days had zero discharge, and the longest period of zero discharge was 58 days_-from May 4 through June 30, 2010.

\section{Stormwater Sampling: Conditions and Results}

During the period July 1, 2009, through June 30, 2010, the flashy nature of the H-1 storm drain created many discharge peaks high enough to sample. For this period, a total of 10 samples were collected and analyzed during three storms: August 12, 2009, March 4, and March 8, 2010. The 10 samples included 1 grab sample, 1 composite sample, and 8 discrete samples.

About 17 peaks over the year had sufficient flow to trigger the automatic sampler; however, most of these peaks were of insufficient duration for a complete sample with multiple samples collected by the automatic sampler. Most of these peaks occurred during October 2009 to March 2010. During the period from July 1 to September 30, 2009, one storm with two peaks was sufficient to trigger the sampler, and samples from this storm were analyzed. The period from April 1 to June 30, 2010, also had one storm that generated enough runoff to trigger the sampler, but the storm was too short to produce a complete sample set.

\section{Third Quarter 2009-July 1 to September 30, 2009}

The hydrograph of discharge for third quarter 2009 (fig. 3) shows two discharge peaks that were high enough to trigger the sampler: one peak during August 12, with a maximum discharge of $6.5 \mathrm{ft}^{3} / \mathrm{s}$, and a second peak during the first 2 hours of August 13, with a maximum discharge of $17 \mathrm{ft}^{3} / \mathrm{s}$. Only the first peak was sampled.

Storm of August 12, 2009

The rain gage at the $\mathrm{H}-1$ storm drain recorded daily rainfall totals of $0.34 \mathrm{in}$. and $1.02 \mathrm{in}$. on August 11 and 12, respectively. About 1.16 in. of rain fell during the period from 20:00 on August 11 to 07:00 on August 12. The peak flow of $6.5 \mathrm{ft}^{3} / \mathrm{s}$ occurred at 03:00. The automatic sampler was triggered 11 times during the storm, from 02:48 to 04:30; however, only 8 sample bottles were filled (fig. 3). The first two samples were processed into a grab sample for $\mathrm{O}+\mathrm{G}$ and $\mathrm{TPH}$ analyses and designated with the mean time between the two sample times, and the remaining six samples were combined for a timecomposite sample. The average discharge for the grab sample (the average of the discharge associated with the first two bottles) was $3.0 \mathrm{ft}^{3} / \mathrm{s}$, and the time-weighted average discharge associated with the composite sample was also $3.0 \mathrm{ft}^{3} / \mathrm{s}$. Discharge, $\mathrm{pH}$, and specific-conductance values from laboratory measurements, constituent concentrations, and loads for the grab and time-composite samples are shown on table 3 in appendix B.

\section{Fourth Quarter 2009-October 1 to December 31, 2009}

Hydrographs of discharge during fourth quarter 2009 are shown in figure 4. Eight storms during the quarter produced sufficient flow to trigger the automatic sampler; however, seven of the storms were of insufficient duration for a complete sample with multiple samples collected by the automatic sampler. The highest discharge peak of the year, at $78 \mathrm{ft}^{3} / \mathrm{s}$, occurred at 19:35 on December 3, 2009. This storm was not sampled. 


\section{First Quarter 2010-January 1 to March 31, 2010}

Hydrographs showing discharge and the storms sampled during January 1 to March 31, 2010, are shown in figure 5. Storms during January 6, February 2 and 7, and March 4, 6, and 8 had sufficient discharge to trigger the automatic samplers. Eight 1-liter sample bottles were filled by the automatic sampler during the January 6 storm. These samples were not analyzed; the emphasis of the effort at that time was to collect samples using the new strategy. Work was being conducted on the station logging systems on February 2, and no samples were collected. With the equipment ready for sampling using the new strategy, the February 7 storm had sufficient flow to trigger the automatic samplers (both $\mathrm{H}-1$ storm drain and Manoa-Palolo Drainage Canal). Although both samplers collected all four samples, the 1gallon jars were only partially filled, and samples had insufficient volume for analyses. The volume of sample pumped was adjusted for the next anticipated storm. Samples collected during the storms of March 4 and March 8, 2010, were analyzed.

Storm of March 4, 2010

The storm of March 4, 2010, was the first storm sampled and analyzed using the new sampling strategy and equipment. The rain gage at the $\mathrm{H}-1$ storm drain recorded a total of $0.25 \mathrm{in}$. of rain on March 4, and it rained 0.13 in. during the hours 20:00 to 23:00. Only one bottle was filled at both samplers during the short-duration peak. The sample was collected at the peak of discharge, which was $3.3 \mathrm{ft}^{3} / \mathrm{s}$ at 23:03. Samples from both the $\mathrm{H}-1$ storm drain and the Manoa-Palolo Drainage Canal were processed and analyzed. Discharge, specific-conductance values from laboratory measurements, constituent concentrations, and loads for the discrete samples are shown on table 3 in appendix B.

\section{Storm of March 8, 2010}

The rain gage at the $\mathrm{H}-1$ storm drain recorded a total of $0.19 \mathrm{in}$. and $0.46 \mathrm{in}$. of rain during March 7 and 8, 2010, respectively, and it rained 0.27 in. during the hours 01:00 to 03:00 on March 8. The maximum discharge for the storm was $7.7 \mathrm{ft}^{3} / \mathrm{s}$ at $02: 11$ on March 8 .

One sample was collected during a brief shower on March 6, and the remaining three samples were collected at 02:06, 02:21, and 03:45 on March 8 at each sampler. The sampler lines were cleaned after the March 4 storm, but they were not cleaned after the sample was collected on March 6. In addition to the TSS, nutrient, and trace metals analyses for the three samples from each site, two $\mathrm{O}+\mathrm{G}$ samples were processed from the first discrete sample from the sites. A field duplicate and a matrix spike analysis were processed using two of the Manoa-Palolo Drainage Canal samples, and a lab duplicate was processed using one of the $\mathrm{H}-1$ storm drain samples. Discharge, specific-conductance values from laboratory measurements, constituent concentrations, and loads for the discrete samples are shown on table 3 in appendix $\mathrm{B}$.

\section{Second Quarter 2010-April 1 to June 30, 2010}

Only one storm caused runoff sufficient to trigger the automatic sampler at the H-1 storm drain during second quarter 2010; it occurred on May 2, 2010 (fig. 6). The storm was of insufficient duration; only one sample was collected from each site. At the time of the storm, it was hoped that a larger storm would occur that would provide more than one sample. 


\section{Quality Assurance}

Field and laboratory quality-assurance procedures were implemented as described in the DOT Storm Water Monitoring Program Plan (State of Hawaii Department of Transportation Highways Division, 2009). Five QA/QC samples were collected during July 1, 2009, to June 30, 2010. Complete results for these samples are not published in this report but are available from the USGS Pacific Islands Water Science Center upon request.

During the March 8, 2010, storm, field-duplicate, laboratory-duplicate, and matrix-spike samples were prepared and analyzed. The field duplicate of one of the Manoa-Palolo Drainage Canal samples showed different results for dissolved chromium, copper, and zinc relative to those of the storm sample. The field duplicate had chromium and zinc concentrations of 0.51 and $6.6 \mu \mathrm{g} / \mathrm{L}$, respectively, whereas the corresponding concentrations for the storm sample were 1.1 and $18.7 \mu \mathrm{g} / \mathrm{L}$. The concentrations of chromium and zinc for the field duplicate are closer in value to those of the previous two samples, collected 84 and 99 minutes earlier, than to those of the storm sample. It is possible that the storm sample bottle may have been contaminated.

An inorganic-blank-water (IBW) sample was collected at the H-1 storm drain and the ManoaPalolo Drainage Canal on January 27, 2010. IBW blank samples were collected after cleaning the sampler intake lines in order to check the effectiveness of the cleaning procedures and detect possible contamination. IBW was run through the sampling apparatus, collected as a sample, and processed similarly to a storm sample. The IBW blank sample was analyzed for total suspended solids, metals, and nutrients at the USGS NWQL. Complete results for the blank samples are not published in this report, but they are available from the USGS Pacific Islands Water Science Center upon request. Zinc commonly has been detected in IBW blank samples from automatic samplers. The IBW blank sample from the Manoa-Palolo Drainage Canal of January 27, 2010, had a zinc concentration of $3.1 \mu \mathrm{g} / \mathrm{L}$.

To reduce the possibility of contamination, the sampling lines were cleaned five times at the $\mathrm{H}-1$ storm drain. Before the collection of the August 12, 2009, sample, the sampler line was cleaned on April 22, 2009, and the drain remained dry throughout the period between the cleaning and August 12 . The sampler bags were replaced on August 7, 2009. The samplers, including the new sampler for the Manoa-Palolo Drainage Canal, were cleaned on January 27, February 12, March 5, and May 5, 2010. In addition, the potential for contamination of the sampler intake line is further reduced because the automatic sampler conducts a rinse cycle before collecting every sample. 


\section{References Cited}

Bodhaine, G.L., 1982, Measurement of peak discharge at culverts by indirect methods: U.S. Geological Survey Techniques of Water-Resources Investigations, book 3, chap. A3, 60p.

Childress, C.J.O., Foreman, W.T., Connor, B.F., and Maloney, T.J., 1999, New reporting procedures based on long-term method detection levels and some considerations for interpretations of waterquality data provided by the U.S. Geological Survey National Water Quality Laboratory: U.S. Geological Survey Open-File Report 99-193, 19 p.

Fishman, M.J., ed., 1993, Methods of analysis by the U.S. Geological Survey National Water Quality Laboratory-determination of inorganic and organic constituents in water and fluvial sediments: U.S. Geological Survey Open-File Report 93-125, 217 p.

Fishman, M.J., and Friedman, L.C., eds., 1989, Methods for determination of inorganic substances in water and fluvial sediments (3d ed.): U.S. Geological Survey Techniques of Water-Resources Investigations, book 5, chap. A1, 545 p.

Friedman, L.C., and Erdmann, D.E., 1982, Quality assurance practices for the chemical and biological analyses of water and fluvial sediments: U.S. Geological Survey Techniques of Water-Resources Investigations, book 5, chap. A6, $181 \mathrm{p}$.

Fulford, J.M., 1995, User's guide to culvert analysis program: U.S. Geological Survey Open-File Report 95-137, 69 p.

Garbarino, J.R., and Struzeski, T.M., 1998, Methods of analysis by the U.S. Geological Survey National Water Quality Laboratory-determination of elements in whole-water digests using inductively coupled plasma-optical emission spectrometry and inductively coupled plasma-mass spectrometry: U.S. Geological Survey Open-File Report 98-165, 101 p.

Garbarino, J.R., Kanagy, L.K., and Cree, M.E., 2006, Determination of elements in natural-water, biota, sediment and soil samples using collision/reaction cell inductively coupled plasma-mass spectrometry: U.S. Geological Survey Techniques and Methods, book 5, sec. B, chap.1, 88 p. Hoffman, G.L., Fishman, M.J., and Garbarino, J.R., 1996, Methods of analysis by the U.S. Geological Survey National Water Quality Laboratory—in-bottle acid digestion of whole-water samples: U.S. Geological Survey Open-File Report 96-225, 28 p.

Patton, C.J., and Truitt, E.P., 1992, Methods of analysis by the U.S. Geological Survey National Water Quality Laboratory-determination of total phosphorus by a Kjeldahl digestion method and an automated colorimetric finish that include dialysis: U.S. Geological Survey Open-File Report 92-146, $42 \mathrm{p}$.

Pritt, J.W., and Raese, J.W., eds., 1992, Quality assurance/quality control manual, National Water Quality Laboratory: U.S. Geological Survey Open-File Report 94-708, 26 p.

Rantz, S.E., and others, 1982, Measurement and computation of streamflow, volume 1. Measurement of stage and discharge, Volume 2. Computation of discharge: U.S. Geological Survey Water-Supply Paper 2175, 284 p. and 346 p.

Sauer, V.B., 2002, Standards for the analysis and processing of surface-water data and information using electronic methods: U.S. Geological Survey Water-Resources Investigations Report 01-4044, $92 \mathrm{p}$.

State of Hawaii Department of Transportation Highways Division, 2008, Annual storm water monitoring program plan 2008-2009, 37 p.

State of Hawaii Department of Transportation Highways Division, 2009, Annual storm water monitoring program plan 2009-2010, 16 p. 
U.S. Environmental Protection Agency, Office of Water, 1993, NPDES storm water sampling guidance manual, prepared by C.K. Smoley: CRC Press, Inc., 165 p.

U.S. Environmental Protection Agency, Region 9, and Hawaii Department of Health, 2002, Revisions to total maximum daily loads for the Ala Wai Canal, Island of Oahu, Hawaii: 37 p., accessed July 15, 2008, at http://hawaii.gov/health/environmental/env-planning/wqm/awtmdlfinal.pdf,.

Wilde, F.D., Radtke, D.B., Gibs, Jacob, and Iwatsubo, R.T., 1998, National field manual for the collection of water-quality data: U.S. Geological Survey Techniques of Water-Resources Investigations, book 9, chap. A4, 114 p. 
$157^{\circ} 49^{\prime}$

$157^{\circ} 48^{\prime} 30^{\prime \prime}$

$157^{\circ} 48^{\prime}$

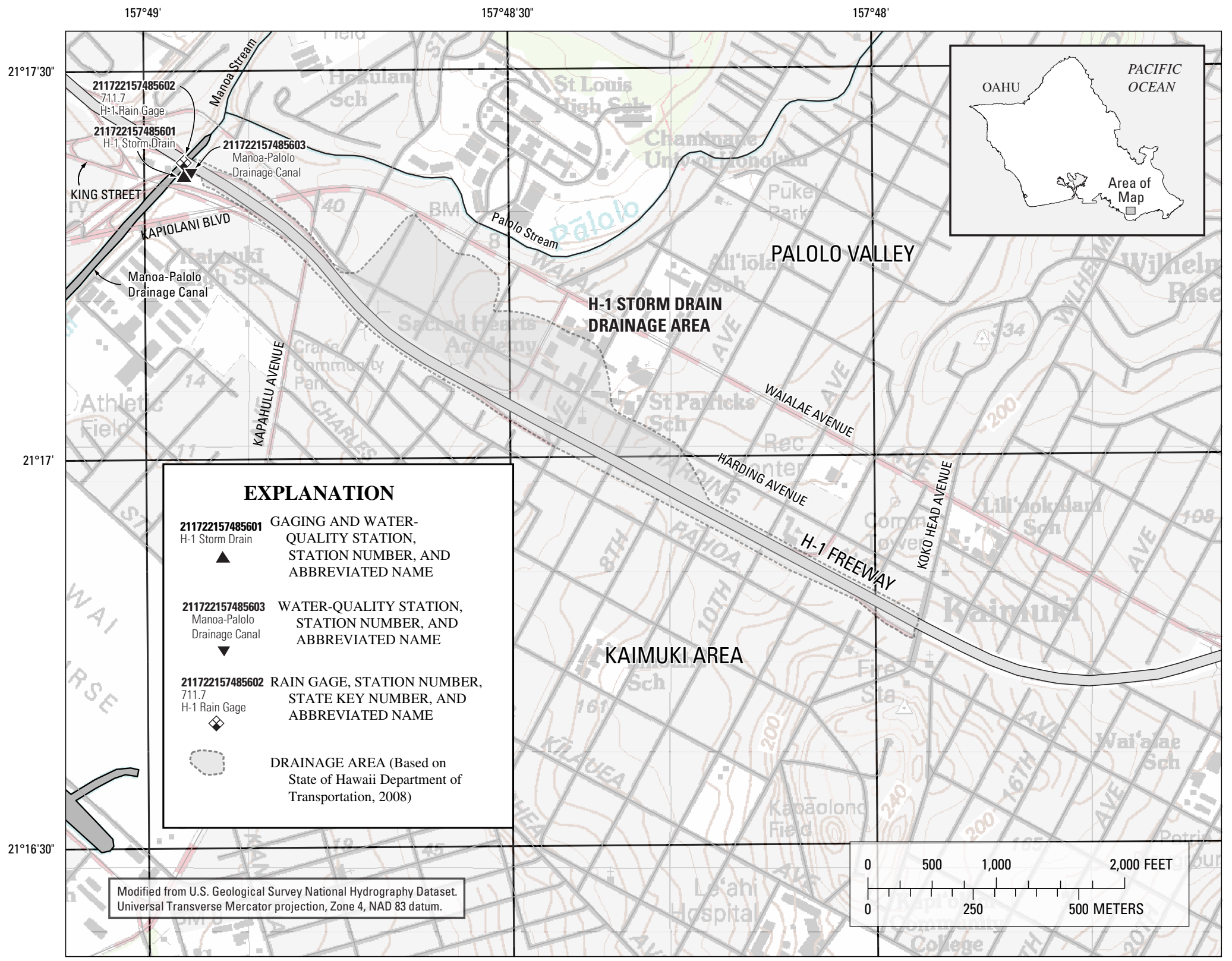

Figure 1. Drainage area of the $\mathrm{H}-1$ storm drain and locations of the $\mathrm{H}-1$ rain gage, $\mathrm{H}-1$ storm drain gage and the $\mathrm{H}-1$ storm drain and Manoa-Palolo Drainage Canal sampling sites, Oahu, Hawaii. 

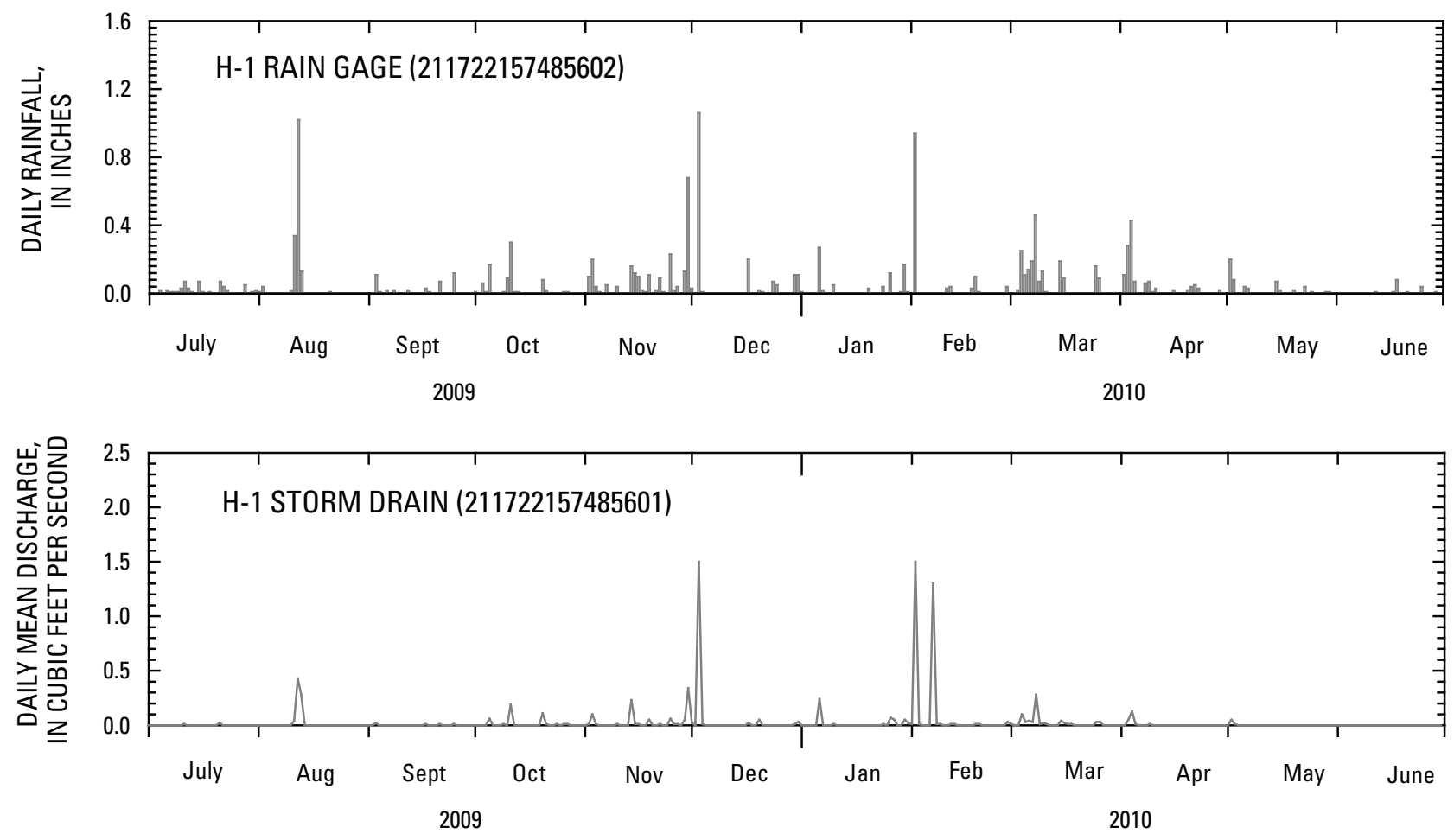

Figure 2. Daily rainfall and daily mean discharge for H-1 rain gage (211722157485602) and H-1 storm drain (211722157485601) within the Ala Wai Canal watershed, Oahu, Hawaii, for July 1, 2009, to June 30, 2010. 

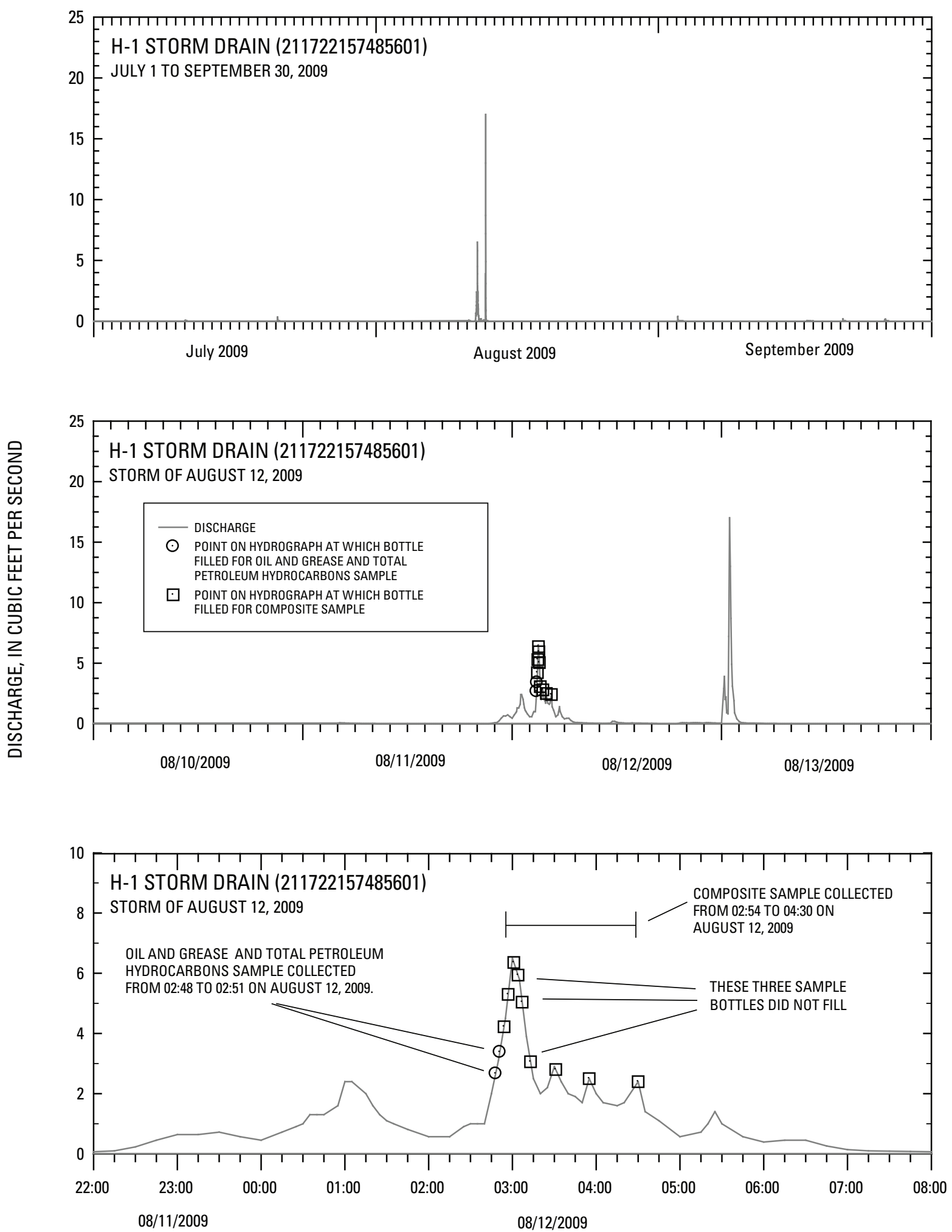

Figure 3. Discharge at H-1 storm drain (211722157485601), Oahu, Hawaii, for July 1 to September 30, 2009 (top), detail of 4-day period from August 10 to 13, 2009 (middle), and detail of 10-hour period from 22:00 August 11 to 08:00 August 12, 2009 (bottom). 


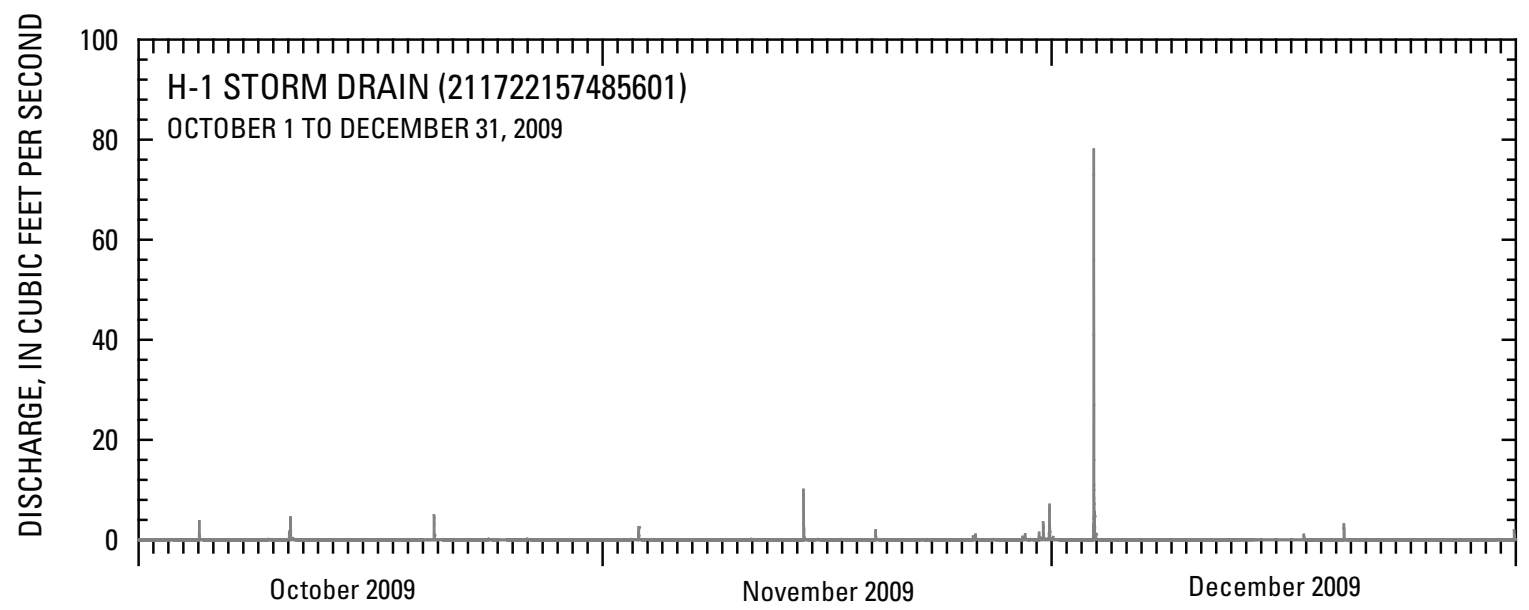

Figure 4. Discharge at H-1 storm drain (211722157485601) for October 1 to December 31, 2009, Oahu, Hawaii. 

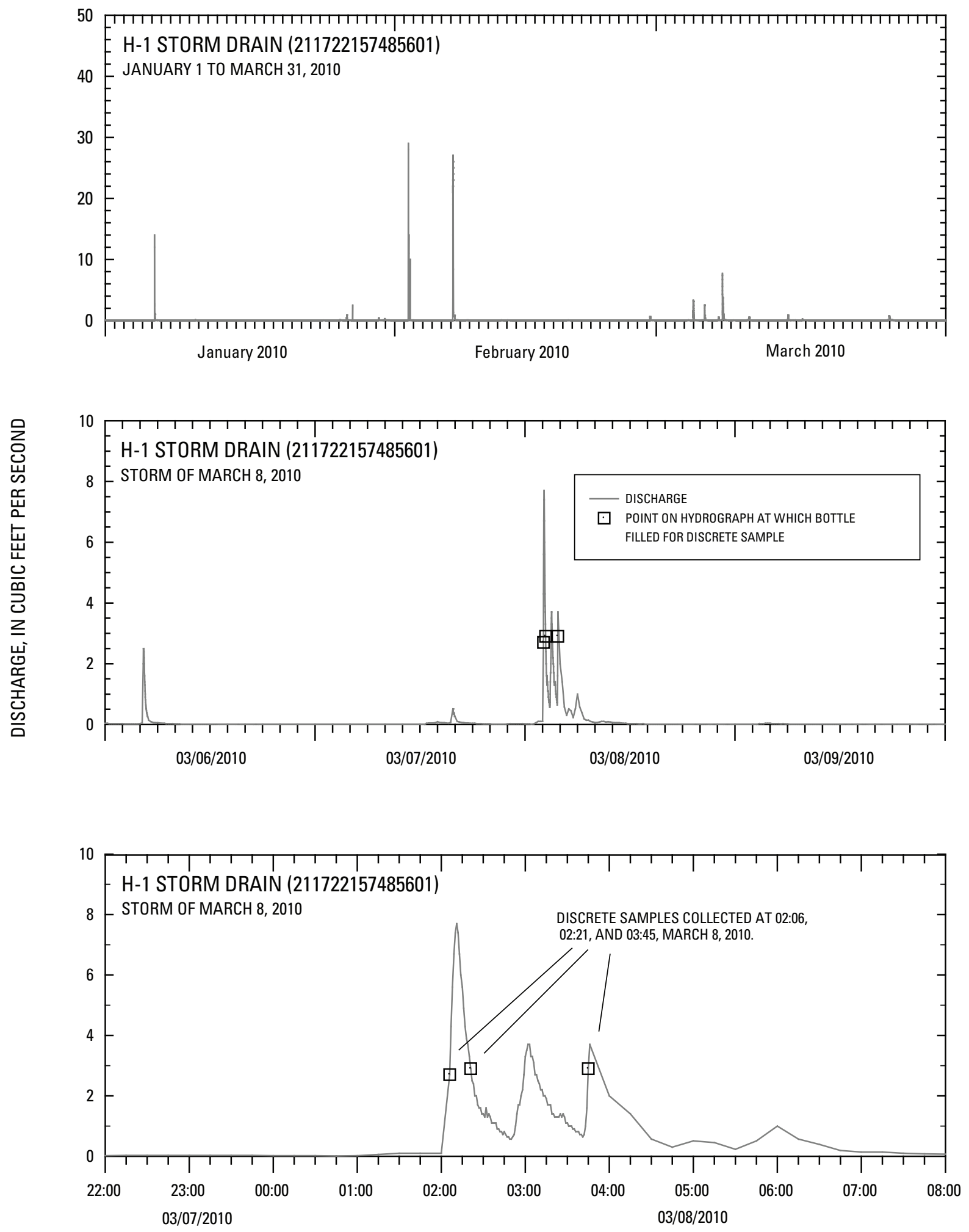

Figure 5. Discharge at H-1 storm drain (211722157485601), Oahu, Hawaii, for January 1 to March 31, 2010 (top), detail of 4-day period from March 6 to 10, 2010 (middle), and detail of 10-hour period from 22:00 March 7 to 08:00 March 8, 2010 (bottom). 


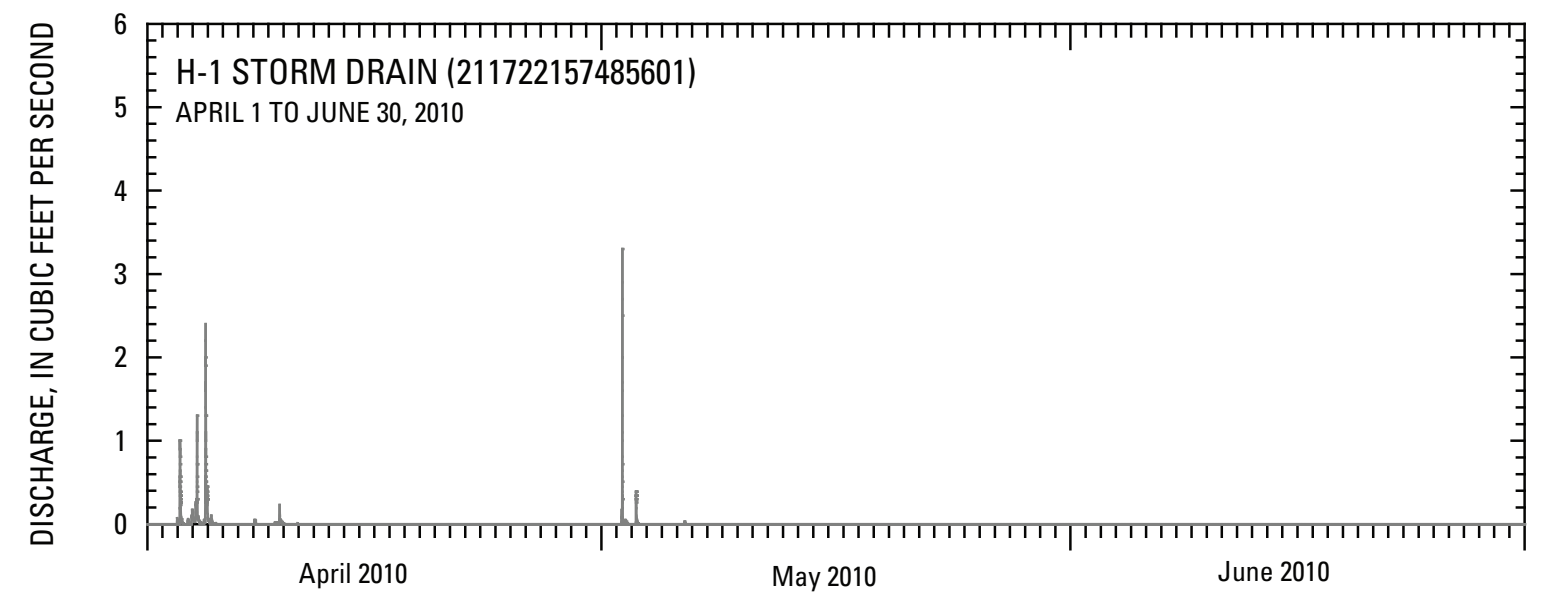

Figure 6. Discharge at H-1 storm drain (211722157485601) for April 1 to June 30, 2010, Oahu, Hawaii. 


\section{Appendix A. Discharge-Reporting and Load-Calculation Methods}

This appendix further defines the methods used for reporting discharge data and constituentconcentration data and the methods for calculating constituent loads. Values for discharge and waterquality data are rounded off to the number of significant figures that best describe the precision of the measurement.

Discharge Data.-Table 1 shows the number of significant figures and rounding limits for the range of discharges used in this study. Discharges measured by current meter or float-measurement techniques follow guidelines for measured discharges. Discharges determined by discharge rating or by averaging follow guidelines for daily mean discharges (Sauer, 2002). Measured discharges may have more significant figures because they are considered more precise than averaged discharges.

Table 1. Significant figures and rounding limits for measured, discharge-rating, and averaged discharges.

$\left[\mathrm{ft}^{3} / \mathrm{s}\right.$, cubic feet per second; <, actual value is less than value shown; $\geq$, actual value is greater than or equal to value shown]

\begin{tabular}{|c|c|c|c|c|}
\hline \multirow[b]{2}{*}{$\begin{array}{l}\text { Range of discharge } \\
\left(\mathrm{ft}^{3} / \mathrm{s}\right)\end{array}$} & \multicolumn{2}{|c|}{ Measured discharge } & \multicolumn{2}{|c|}{ Discharge-rating and averaged discharges } \\
\hline & Significant figures & Rounding limit & Significant figures & Rounding limit \\
\hline$<0.10$ & 2 & thousandths & 1 & hundredths \\
\hline$\geq 0.10$ and $<1.0$ & 2 & hundredths & 2 & hundredths \\
\hline$\geq 1.0$ and $<10$ & 3 & hundredths & 2 & tenths \\
\hline$\geq 10$ and $<100$ & 3 & tenths & 2 & units \\
\hline$\geq 100$ & 3 & variable & 3 & variable \\
\hline
\end{tabular}

Calculation of loads. - Table 2 shows the conversion factors used for determining constituent loads. Constituent loads for all analyses are reported as pounds per day (lbs/day). All loads are the product of constituent concentration multiplied by associated discharge and the appropriate conversion factor (equation 1). Concentrations are reported in milligrams per liter $(\mathrm{mg} / \mathrm{L})$ or micrograms per liter $(\mu \mathrm{g} / \mathrm{L})$.

Because the values of concentrations are multiplied by the discharge, a significant-figure rule applies for cases where the number of significant figures for each value is different by at least two figures. In these cases, the value with the greater number of significant figures is rounded off to contain one more significant figure than the value with the lesser number of significant figures before multiplying the values. The load value is reported with the number of significant figures of the value (concentration or discharge) with the least number of significant figures. This significant-figure rule is not applied to the conversion factor, which has four significant figures.

$$
\begin{aligned}
Q(C) K=L, \\
\text { where } Q=\operatorname{discharge}\left(\mathrm{ft}^{3} / \mathrm{s}\right) \\
C=\text { constituent concentration }(\mathrm{mg} / \mathrm{L} \text { or } \mu \mathrm{g} / \mathrm{L}) \\
\mathrm{K}=\text { conversion factor } \\
L=\text { constituent load }(\mathrm{bs} / \mathrm{day})
\end{aligned}
$$


Table 2. Conversion factors for computing daily loads from constituent concentration and discharge. [mg/L, milligrams per liter; $\mu \mathrm{g} / \mathrm{L}$, micrograms per liter; lbs/day, pounds per day] Unit of concentration Conversion factor ${ }^{1}$

Load unit $\mathrm{mg} / \mathrm{L}$ $\mu \mathrm{g} / \mathrm{L}$ 5.394 0.005394

lbs/day lbs/day

${ }^{1}$ All conversion factors are based on discharge in cubic feet per second. 
Appendix B. Physical Properties, Concentrations, and Loads for All Samples Collected from the H-1 Storm Drain and the Manoa-Palolo Drainage Canal During the Period from July 1, 2009, to June 30, 2010, Oahu, Hawaii 
Table 3. Physical properties, concentrations, and loads for all samples collected from the H-1 storm drain and the Manoa-Palolo Drainage Canal during the period July 1, 2009 to June 30, 2010, Oahu, Hawaii. [hh:mm, hours and minutes; Grab, intitial samples, analyzed separately for specific constituents; Composite, time-composite sample; Discrete, fixed time interval samples, analyzed separately;

Instant, value of instantaneous discharge; Avg., value of average discharge for time-composite samples; \#, discharge value from streamflow rating; Conc., concentration; Load, computed from concentration value

and discharge value for each sample, load

value shown; $\mathrm{e}$, value is estimated; --, not analyzed or measured; $\mathrm{N}$, nitrogen; $\mu \mathrm{S} / \mathrm{cm}$, microsiemens per centimeter; ft $\mathrm{ft} / \mathrm{s}$, cubic feet per second; $\mathrm{mg} / \mathrm{L}$, milligrams per liter; ;b/day, pounds per day; $\mu g / L$, micrograms per liter]

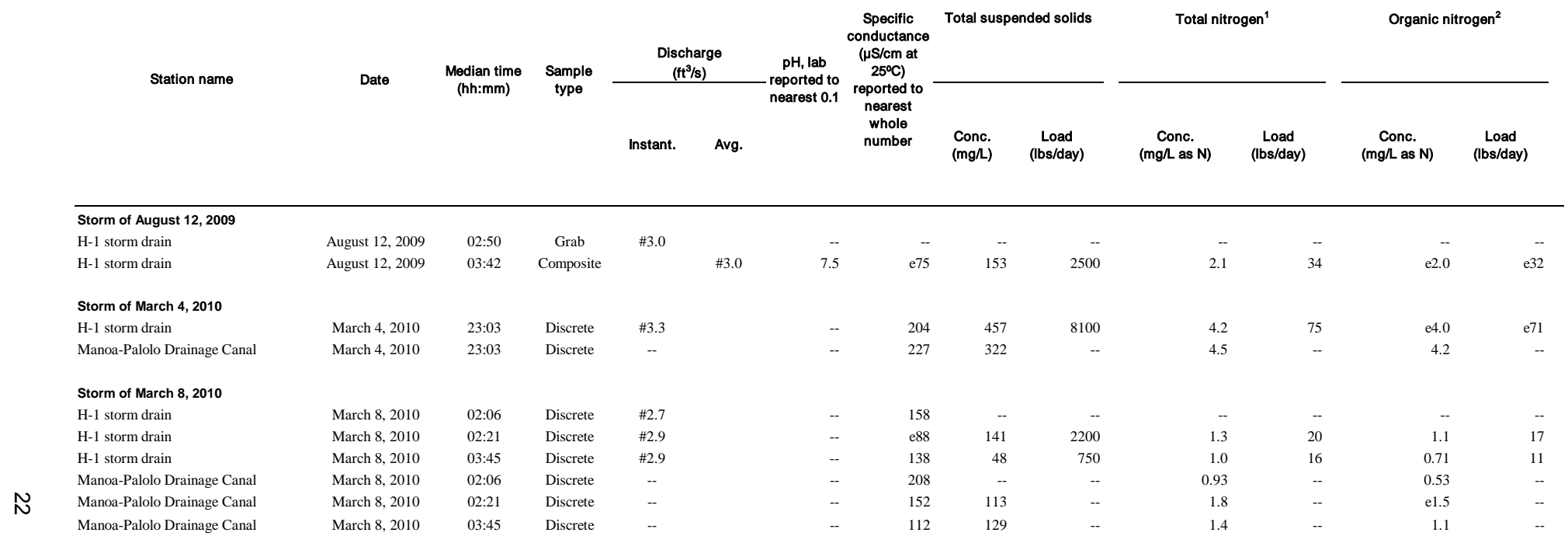


Table 3. Physical properties, concentrations, and loads for all samples collected from the H-1 storm drain and the Manoa-Palolo Drainage Canal during the period July 1, 2009 to June 30, 2010, Oahu, Hawaii--Continued [hh:mm, hours and minutes; Grab, initial samples, analyzed separately for specificic constituents; Composite, time-composite sample; Discrete, fixed time interval samples, analyzed separately;

Instant, value of instantaneous discharge; Avg., value of average discharge for time-composite samples; \#, discharge value from streamflow rating; Conc., concentration; Load, computed from concentration value

and discharge value for each sample, loads ass

value shown; $\mathrm{e}$, value is estimated; --, not analyzed or measured; $\mathrm{N}$, nitrogen; $\mu \mathrm{S} / \mathrm{cm}$, microsiemens per centimeter; ft $\mathrm{ft} / \mathrm{s}$, cubic feet per second; $\mathrm{mg} / \mathrm{L}$, milligrams per liter; ;bs/day, pounds per day; $\mu g / L$, micrograms per liter

\begin{tabular}{|c|c|c|c|c|c|c|c|c|c|c|c|c|c|c|c|}
\hline \multirow{2}{*}{ Station name } & \multirow{2}{*}{ Date } & \multirow{2}{*}{$\begin{array}{l}\text { Median time } \\
\text { (hh:mm) }\end{array}$} & \multirow{2}{*}{$\begin{array}{c}\text { Sample } \\
\text { type }\end{array}$} & \multicolumn{2}{|c|}{$\begin{array}{l}\text { Ammonia } \\
\text { dissolved }\end{array}$} & \multicolumn{2}{|c|}{$\begin{array}{c}\text { Total } \\
\text { Ammonia }\end{array}$} & \multicolumn{2}{|c|}{$\begin{array}{c}\text { Nitrogen, total organic + } \\
\text { ammonia }\end{array}$} & \multicolumn{2}{|c|}{$\begin{array}{l}\text { Nitrogen, nitrite } \\
\text { +nitrate dissolved }\end{array}$} & \multicolumn{2}{|c|}{$\begin{array}{l}\text { Phosphorus } \\
\text { dissolved }\end{array}$} & \multicolumn{2}{|c|}{ Total phosphorus } \\
\hline & & & & $\begin{array}{c}\text { Conc. } \\
\text { (mg/L as N) }\end{array}$ & $\begin{array}{l}\text { Load } \\
\text { (lbs/day) }\end{array}$ & $\begin{array}{c}\text { Conc. } \\
\text { (mg/L as N) }\end{array}$ & $\begin{array}{l}\text { Load } \\
\text { (lbs/day) }\end{array}$ & $\begin{array}{c}\text { Conc. } \\
\text { (mg/L as } \mathrm{N})\end{array}$ & $\begin{array}{l}\text { Load } \\
\text { (lbs/day) }\end{array}$ & $\begin{array}{c}\text { Conc. } \\
\text { (mg/L as N) }\end{array}$ & $\begin{array}{l}\text { Load } \\
\text { (lbs/day) }\end{array}$ & $\begin{array}{l}\text { Conc. } \\
\text { (mg/L) }\end{array}$ & $\begin{array}{l}\text { Load } \\
\text { (lbs/day) }\end{array}$ & $\begin{array}{l}\text { Conc. } \\
\text { (mg/L) }\end{array}$ & $\begin{array}{l}\text { Load } \\
\text { (lbs/day) }\end{array}$ \\
\hline \multicolumn{16}{|l|}{ Storm of August 12, 2009} \\
\hline H-1 storm drain & August 12, 2009 & 02:50 & Grab & -- & -- & -- & -- & -- & -- & -- & -- & -- & -- & -- & -. \\
\hline H-1 storm drain & August 12, 2009 & 03:42 & Composite & $<0.020$ & $<0.32$ & e0.03 & e0.5 & 2.0 & 32 & 0.09 & 1 & 0.09 & 1 & 0.56 & 9.1 \\
\hline \multicolumn{16}{|l|}{ Storm of March 4, 2010} \\
\hline H-1 storm drain & March 4, 2010 & 23:03 & Discrete & $<0.020$ & $<0.36$ & e0.04 & e0.7 & 4.0 & 71 & 0.16 & 2.8 & 0.13 & 2.3 & 1.31 & 23 \\
\hline Manoa-Palolo Drainage Canal & March 4, 2010 & 23:03 & Discrete & $<0.020$ & - & 0.04 & -- & 4.2 & -- & 0.33 & -- & 0.04 & -- & 0.87 & -- \\
\hline \multicolumn{16}{|l|}{ Storm of March 8, 2010} \\
\hline H-1 storm drain & March 8, 2010 & 02:06 & Discrete & 0.022 & 0.32 & -- & -- & -- & -- & 0.18 & 2.6 & 0.07 & 1 & - & -- \\
\hline H-1 storm drain & March 8, 2010 & 02:21 & Discrete & 0.024 & 0.38 & 0.07 & 1 & 1.2 & 19 & 0.11 & 1.7 & 0.08 & 1 & 0.45 & 7.0 \\
\hline H-1 storm drain & March 8, 2010 & 03:45 & Discrete & 0.044 & 0.69 & 0.06 & 0.9 & 0.77 & 12 & 0.28 & 4.4 & 0.08 & 1 & 0.20 & 3.1 \\
\hline Manoa-Palolo Drainage Canal & March 8, 2010 & 02:06 & Discrete & 0.023 & -- & 0.05 & - & 0.58 & -- & 0.35 & - & $\mathrm{e} 0.04$ & -- & 0.12 & -- \\
\hline Manoa-Palolo Drainage Canal & March 8, 2010 & 02:21 & Discrete & $<0.020$ & - & e0.04 & -- & 1.5 & -- & 0.27 & -- & 0.07 & -- & 0.39 & -- \\
\hline Manoa-Palolo Drainage Canal & March 8, 2010 & 03:45 & Discrete & 0.025 & -- & 0.06 & -- & 1.2 & -- & 0.19 & -- & 0.07 & -- & 0.38 & -- \\
\hline
\end{tabular}


Table 3. Physical properties, concentrations, and loads for all samples collected from the H-1 storm drain and the Manoa-Palolo Drainage Canal during the period July 1, 2009 to June 30, 2010, Oahu, Hawaii--Continued [hh:mm, hours and minutes; Grab, initial samples, analyzed separately for specificic constituents; Composite, time-composite sample; Discrete, fixed time interval samples, analyzed separately;

Instant, value of instantaneous discharge; Avg., value of average discharge for time-composite samples; \#, discharge value from streamflow rating; Conc., concentration; Load, computed from concentration valu

and discharge value for each sample, loads associated wh grab samples are instantaneous loads, loads associated whicomposite samples are average loads; ; Conce, concentration; < < actual value is less than the

value shown; e, value is estimated; ;-, not analyzed or measured; $\mathrm{N}$, nitrogen; $\mu \mathrm{S} / \mathrm{cm}$, microsiemens per centimeter; $\mathrm{ft3} / \mathrm{s}$, cubbic feet per second; $\mathrm{mg} / \mathrm{L}$,milligrams per liter; , bs/day, pounds per day; $\mu g / \mathrm{L}$,micrograms per liter]

\begin{tabular}{|c|c|c|c|c|c|c|c|c|c|c|c|c|c|}
\hline \multirow{2}{*}{ Station name } & \multirow{2}{*}{ Date } & \multirow{2}{*}{$\begin{array}{l}\text { Median time } \\
\text { (hh:mm) }\end{array}$} & \multirow{2}{*}{$\begin{array}{c}\text { Sample } \\
\text { type }\end{array}$} & \multicolumn{2}{|c|}{$\begin{array}{l}\text { Dissolved } \\
\text { cadmium }\end{array}$} & \multicolumn{2}{|c|}{ Total cadmium } & \multicolumn{2}{|c|}{$\begin{array}{l}\text { Dissolved } \\
\text { chromium }\end{array}$} & \multicolumn{2}{|c|}{ Total chromium } & \multicolumn{2}{|c|}{$\begin{array}{c}\text { Dissolved } \\
\text { copper }\end{array}$} \\
\hline & & & & $\begin{array}{l}\text { Conc. } \\
(\mu g / L)\end{array}$ & $\begin{array}{l}\text { Load } \\
\text { (lbs/day) }\end{array}$ & $\begin{array}{l}\text { Conc. } \\
(\mu g / L)\end{array}$ & $\begin{array}{l}\text { Load } \\
\text { (lbs/day) }\end{array}$ & $\begin{array}{l}\text { Conc. } \\
(\mu g / L)\end{array}$ & $\begin{array}{l}\text { Load } \\
\text { (lbs/day) }\end{array}$ & $\begin{array}{l}\text { Conc. } \\
(\mu g / L)\end{array}$ & $\begin{array}{l}\text { Load } \\
\text { (lbs/day) }\end{array}$ & $\begin{array}{l}\text { Conc. } \\
(\mu g / L)\end{array}$ & $\begin{array}{l}\text { Load } \\
\text { (lbs/day) }\end{array}$ \\
\hline \multicolumn{14}{|l|}{ Storm of August 12, 2009} \\
\hline H-1 storm drain & August 12, 2009 & 02:50 & Grab & -- & -- & -- & -- & - & - & -- & -- & -- & -- \\
\hline H-1 storm drain & August 12, 2009 & 03:42 & Composite & $\mathrm{e} 0.01$ & e0.0002 & 0.55 & 0.0089 & 1.1 & 0.018 & 15.3 & 0.25 & 6.6 & 0.11 \\
\hline \multicolumn{14}{|l|}{ Storm of March 4, 2010} \\
\hline H-1 storm drain & March 4, 2010 & 23:03 & Discrete & 0.05 & 0.0009 & -- & -- & 3.9 & 0.069 & -- & -- & 19.7 & 0.35 \\
\hline Manoa-Palolo Drainage Canal & March 4, 2010 & 23:03 & Discrete & $<0.02$ & - & -- & -- & 0.48 & -- & -- & -- & 4.3 & -- \\
\hline \multicolumn{14}{|l|}{ Storm of March 8, 2010} \\
\hline H-1 storm drain & March 8, 2010 & 02:06 & Discrete & 0.04 & 0.0006 & -- & -- & 1.7 & 0.025 & - & -- & 10.9 & 0.16 \\
\hline H-1 storm drain & March 8, 2010 & 02:21 & Discrete & $\mathrm{e} 0.02$ & $\mathrm{e} 0.0003$ & -- & -- & 0.81 & 0.013 & -- & -- & 6.3 & 0.099 \\
\hline H-1 storm drain & March 8, 2010 & 03:45 & Discrete & $\mathrm{e} 0.02$ & $\mathrm{e} 0.0003$ & -- & -. & 0.55 & 0.0086 & -. & -- & 4.6 & 0.072 \\
\hline Manoa-Palolo Drainage Canal & March 8, 2010 & 02:06 & Discrete & $<0.02$ & -- & -- & -- & 0.55 & -- & -- & -- & 5.6 & -- \\
\hline Manoa-Palolo Drainage Canal & March 8, 2010 & 02:21 & Discrete & $<0.02$ & -- & -- & -- & 0.57 & - & -- & -- & 4.9 & -- \\
\hline Manoa-Palolo Drainage Canal & March 8, 2010 & 03:45 & Discrete & $\mathrm{e} 0.02$ & -- & -- & -- & $1.1^{3}$ & -- & -- & -- & 6.9 & -- \\
\hline
\end{tabular}


Table 3. Physical properties, concentrations, and loads for all samples collected from the H-1 storm drain and the Manoa-Palolo Drainage Canal during the period July 1, 2009 to June 30, 2010, Oahu, Hawaii--Continued [hh:mm, hours and minutes; Grab, initial samples, analyzed separately for specificic constituents; Composite, time-composite sample; Discrete, fixed time interval samples, analyzed separately;

Instant, value of instantaneous discharge; Avg., value of average discharge for time-composite samples; \#, discharge value from streamflow rating; Conc., concentration; Load, computed from concentration valu

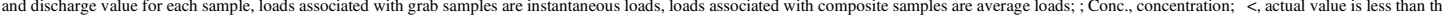

value shown; e, value is estimated; ;-, not analyzed or measured; $\mathrm{N}$, nitrogen; $\mu \mathrm{S} / \mathrm{cm}$, microsiemens per centimeter; $\mathrm{ft3} / \mathrm{s}$, cubbic feet per second; $\mathrm{mg} / \mathrm{L}$,milligrams per liter; , bs/day, pounds per day; $\mu g / \mathrm{L}$,micrograms per liter]

\begin{tabular}{|c|c|c|c|c|c|c|c|c|c|c|c|c|c|}
\hline \multirow{2}{*}{ Station name } & \multirow{2}{*}{ Date } & \multirow{2}{*}{$\begin{array}{l}\text { Median time } \\
(\mathrm{hh}: \mathrm{mm})\end{array}$} & \multirow{2}{*}{$\begin{array}{l}\text { Sample } \\
\text { type }\end{array}$} & \multicolumn{2}{|c|}{ Total copper } & \multicolumn{2}{|c|}{$\begin{array}{l}\text { Dissolved } \\
\text { lead }\end{array}$} & \multicolumn{2}{|c|}{ Total lead } & \multicolumn{2}{|c|}{$\begin{array}{l}\text { Dissolved } \\
\text { nickel }\end{array}$} & \multicolumn{2}{|c|}{ Total nickel } \\
\hline & & & & $\begin{array}{l}\text { Conc. } \\
(\mu g / L)\end{array}$ & $\begin{array}{l}\text { Load } \\
\text { (lbs/day) }\end{array}$ & $\begin{array}{l}\text { Conc. } \\
(\mu g / L)\end{array}$ & $\begin{array}{l}\text { Load } \\
\text { (lbs/day) }\end{array}$ & $\begin{array}{l}\text { Conc. } \\
(\mu g / L)\end{array}$ & $\begin{array}{l}\text { Load } \\
\text { (lbs/day) }\end{array}$ & $\begin{array}{l}\text { Conc. } \\
(\mu g / L)\end{array}$ & $\begin{array}{c}\text { Load } \\
\text { (lbs/day) }\end{array}$ & $\begin{array}{l}\text { Conc. } \\
(\mu g / L)\end{array}$ & $\begin{array}{l}\text { Load } \\
\text { (lbs/day) }\end{array}$ \\
\hline \multicolumn{14}{|l|}{ Storm of August 12, 2009} \\
\hline $\mathrm{H}-1$ storm drain & August 12, 2009 & 02:50 & Grab & - & -- & - & -- & -- & -- & -- & -- & -- & -- \\
\hline H-1 storm drain & August 12, 2009 & 03:42 & Composite & 586 & 9.5 & 0.48 & 0.0078 & 75.9 & 1.2 & 1.2 & 0.019 & 17.8 & 0.29 \\
\hline \multicolumn{14}{|l|}{ Storm of March 4, 2010} \\
\hline H-1 storm drain & March 4, 2010 & 23:03 & Discrete & -- & - & 0.99 & 0.018 & -- & -- & 2.9 & 0.052 & -- & -- \\
\hline Manoa-Palolo Drainage Canal & March 4, 2010 & 23:03 & Discrete & -- & - & 0.18 & -- & - & -- & 1.1 & -- & -- & -- \\
\hline \multicolumn{14}{|l|}{ Storm of March 8, 2010} \\
\hline H-1 storm drain & March 8, 2010 & 02:06 & Discrete & -- & - & 0.33 & 0.0048 & -- & -- & 1.8 & 0.026 & -- & -- \\
\hline H-1 storm drain & March 8, 2010 & $02: 21$ & Discrete & -- & - & 0.46 & 0.0072 & - & -- & 0.83 & 0.013 & - & -- \\
\hline $\mathrm{H}-1$ storm drain & March 8, 2010 & 03:45 & Discrete & -- & -- & 0.18 & 0.0028 & -- & -- & 0.68 & 0.011 & -. & -- \\
\hline Manoa-Palolo Drainage Canal & March 8, 2010 & 02:06 & Discrete & -- & - & 0.23 & - & - & - & 0.69 & -- & -- & -- \\
\hline Manoa-Palolo Drainage Canal & March 8, 2010 & $02: 21$ & Discrete & -- & - & 0.22 & -- & - & -- & 0.79 & -- & -- & -- \\
\hline Manoa-Palolo Drainage Canal & March 8, 2010 & 03:45 & Discrete & -- & -- & 0.39 & -- & -- & -- & 0.9 & -- & -- & -- \\
\hline
\end{tabular}


Table 3. Physical properties, concentrations, and loads for all samples collected from the H-1 storm drain and the Manoa-Palolo Drainage Canal during the period July 1, 2009 to June 30, 2010, Oahu, Hawaii--Continued. [hh:mm, hours and minutes; Grab, initial samples, analyzed separately for specific constituents; Composite, time-composite sample; Discrete, fixed time interval samples, analyzed separately;

Instant, value of instantaneous discharge; Avg., value of average discharge for time-composite samples; \#, discharge value from streamflow rating; Conc., concentration; Load, computed from concentration value

value shown; $\mathrm{e}$, value is estimated; --, not analyzed or measured; $\mathrm{N}$, nitrogen; $\mu \mathrm{S} / \mathrm{cm}$, microsiemens per centimeter; $\mathrm{ft} 3 / \mathrm{s}$, cubic feet per second; $\mathrm{mg} / \mathrm{L}$, milligrams per liter; ;bs/day, pounds per day; $\mu g / L$, micrograms per liter]

\begin{tabular}{|c|c|c|c|c|c|c|c|c|c|c|c|}
\hline \multirow{2}{*}{ Station name } & \multirow{2}{*}{ Date } & \multirow{2}{*}{$\begin{array}{l}\text { Median time } \\
(\mathrm{hh}: \mathrm{mm})\end{array}$} & \multirow{2}{*}{$\begin{array}{c}\text { Sample } \\
\text { type }\end{array}$} & \multicolumn{2}{|c|}{$\begin{array}{l}\text { Dissolved } \\
\text { zinc }\end{array}$} & \multicolumn{2}{|c|}{ Total zinc } & \multicolumn{2}{|c|}{ Oil and grease } & \multicolumn{2}{|c|}{$\begin{array}{l}\text { Total petroleum } \\
\text { hydrocarbons }\end{array}$} \\
\hline & & & & $\begin{array}{l}\text { Conc. } \\
(\mu g / L)\end{array}$ & $\begin{array}{l}\text { Load } \\
\text { (Ibs/day) }\end{array}$ & $\begin{array}{l}\text { Conc. } \\
(\mu g / L)\end{array}$ & $\begin{array}{l}\text { Load } \\
\text { (Ibs/day) }\end{array}$ & $\begin{array}{l}\text { Conc. } \\
\text { (mg/L) }\end{array}$ & $\begin{array}{l}\text { Load } \\
\text { (lbs/day) }\end{array}$ & $\begin{array}{l}\text { Conc. } \\
\text { (mg/L) }\end{array}$ & $\begin{array}{l}\text { Load } \\
\text { (lbs/day) }\end{array}$ \\
\hline \multicolumn{12}{|l|}{ Storm of August 12, 2009} \\
\hline H-1 storm drain & August 12, 2009 & 02:50 & Grab & -- & -- & -- & - & 5.1 & 83 & e3.4 & e55 \\
\hline H-1 storm drain & August 12, 2009 & 03:42 & Composite & 20.5 & 0.33 & 425 & 6.9 & -- & -- & -- & -- \\
\hline \multicolumn{12}{|l|}{ Storm of March 4, 2010} \\
\hline H-1 storm drain & March 4, 2010 & 23:03 & Discrete & 36.8 & 0.66 & -- & - & -- & -- & -- & -- \\
\hline Manoa-Palolo Drainage Canal & March 4, 2010 & 23:03 & Discrete & 2.9 & -- & -- & -- & -- & -- & -- & -- \\
\hline \multicolumn{12}{|l|}{ Storm of March 8, 2010} \\
\hline H-1 storm drain & March 8, 2010 & 02:06 & Discrete & 21.7 & 0.32 & -- & -- & e7.9 & 120 & -- & -- \\
\hline H-1 storm drain & March 8, 2010 & 02:21 & Discrete & 9.2 & 0.14 & -- & - & - & -- & -- & -- \\
\hline H-1 storm drain & March 8, 2010 & 03:45 & Discrete & 7.0 & 0.11 & -- & -- & -- & -- & -- & - \\
\hline Manoa-Palolo Drainage Canal & March 8, 2010 & 02:06 & Discrete & 5.1 & -- & -- & -- & e5.0 & -- & -- & -- \\
\hline Manoa-Palolo Drainage Canal & March 8, 2010 & 02:21 & Discrete & 4.3 & -- & -- & -- & -- & -- & -- & -- \\
\hline Manoa-Palolo Drainage Canal & March 8, 2010 & 03:45 & Discrete & $18.7^{3}$ & -- & -- & -- & -- & -- & -- & .- \\
\hline
\end{tabular}

${ }^{1}$ Total nitrogen is calculated by adding nitrogen, total organic + ammonia (Kjeldahl), to nitrogen, nitrite + nitrate, dissolved.

Ton value of total ammonia is estimated, the concentration value of organic nitrogen is reported as

the difference between the values shown for nitrogen, total organic + ammonia (Kjeldahl), and total ammonia, and noted as estimated.

${ }_{3}^{3}$ Values for copper and zinc $\mathrm{n}$ the

zinc concentrations from the field duplicate agree more closely with the previous two samples. Possible cause for the discrepancy might be the contamination of the sample bottle during preparation or sample processing

The analyses for the field duplicate are available upon reques. 